\title{
Antibacterial Mechanisms of the Urinary Bladder
}

\author{
Carl W. Norden, Gareth M. Green, and Edward H. Kass \\ From the Thorndike Memorial and Channing Laboratories, Department of \\ Medical Microbiology, and Harvard Medical Unit, Boston City Hospital; \\ and the Department of Medicine, Harvard Medical School, \\ Boston, Massachusetts 02118
}

A в S T RACT The disappearance of bacteria from the normal urinary bladder is apparently a function of two host defense mechanisms: the mechanical clearance of organisms by voiding, and the antibacterial activity of the bladder wall. This study quantified the relative contribution of each of these mechanisms to the resistance of the bladder to bacterial infection.

${ }^{32}$ Phosphorus-labeled E. coli, S. aureus, and $P$. mirabilis were each injected into the urinary bladders of unanesthetized female guinea pigs. At intervals after voiding, the bladders were removed, washed, homogenized, and assayed for residual radioactivity and viable bacteria. Mechanical clearance was measured by the changes in total radioactive count. Antibacterial activity was quantified by comparing the bacterial to radioactive ratios of the original bacterial inoculum with similar ratios in the bladder homogenates.

More than $99.9 \%$ of the bladder inoculum was rapidly excreted and about $0.1 \%\left(10^{4}-10^{5}\right)$ organisms remained attached to the bladder wall. Of those $E$. coli attached to the bladder, rapid sequential reduction in viability occurred and reached a level of $85 \%$ loss at $30 \mathrm{~min}$ after inoculation. $4 \mathrm{hr}$ after challenge, less than $10 \%$ of those organisms still attached to the bladder mucosa remained viable. $P$. mirabilis was handled with equal facility, but $S$. aureus showed a reduction in viability of only $46 \%$ at $1 \mathrm{hr}$ and $67 \%$ at $4 \mathrm{hr}$ after inoculation. 6

Part of this work appeared in abstract form in 1968 Clin. Res. 16: 333 .

Address requests for reprints to Dr. Edward H. Kass, Channing Laboratory, Boston City Hospital, 818 Harrison Avenue, Boston, Mass. 02118.

Received for publication 9 May 1968 and in revised form 24 August 1968. hr after infection with S. aureus, 6 of 12 guinea pig bladders showed multiplication of the organisms still attached to the bladder wall; only 1 of 12 animals challenged with $E$. coli had comparable multiplication.

The mechanism whereby the bladder wall kills bacteria is unclear, but it did not appear to be related to an antibacterial activity of urine, clumping of organisms on bladder mucosa, phagocytosis by leukocytes, or serum levels of bactericidal antibody. Although it is clear that the bladder exhibits intrinsic antibacterial properties, the role of this defense mechanism in the pathogenesis of urinary tract infection requires further clarification.

\section{INTRODUCTION}

Multiplication of bacteria within the bladder may lead to ascending infection of the urinary tract by spread of bacteria up the ureters and invasion of the kidneys $(1,2)$. Clinical observations and laboratory studies in man (3) and experimental animals (4) have confirmed that when bacteria are introduced into the bladder, they often disappear from the urine. Those instances in which the genitourinary tract fails to rid itself of bacteria may be viewed as instances of a failure of host mechanisms of resistance to bacterial infection.

A significant part of bladder defense is the capacity to excrete large numbers of organisms in the urine (5). However, the quantity of bacteria remaining in the bladder after voiding is sufficient, if its growth is uninhibited, to perpetuate infection. The fact that the bladder does become sterile suggests that there is an additional mechanism which deals with those residual organisms. The experi- 
ments of Vivaldi, Muñoz, Cotran, and Kass (6) and of Cobbs and Kaye (7) indicate that the bladder exerts a bactericidal action on bacteria, although this concept has been disputed by Paquin, Perez, Kunin, and Foster (8) and by Mulholland, Foster, Gillenwater, and Paquin (9).

In all previous studies the experimental animals were anesthetized and manipulated surgically. Furthermore, since such studies were concerned with the antibacterial action of bladder mucosa, as distinct from voiding mechanisms, there has been no study of the interactions between voiding and antibacterial defense systems within the bladder.

A simple model has been developed in this laboratory that permits the use of normally voiding infected animals. Radiolabeled bacteria are introduced into the bladder and the relative numbers of organisms removed mechanically by roiding and rendered nonviable by the bladder wall are determined. With this model, evidence of rapid and efficient killing of bacteria by the bladder was obtained, and the interaction of this mechanism with the voiding mechanism was assessed. A series of experiments attempted to identify the nature of this antibacterial bladder activity.

\section{METHODS}

Guinea pigs and rats were inoculated intravesically with a radiotracer-labeled overnight broth culture of $E$. coli, $P$. mirabilis, or $S$. aureus. At intervals after the inoculation the animals were killed and the bladders removed. Quantitative measurements of radioactivity and of viable bacteria were made on the original inocula and bladder homogenates. From these data, the antibacterial effects of voiding and of bladder mucosa were calculated.

Preparation of radioactive inoculum. The strain of $E$. coli used in these experiments was obtained from the urine of a patient with acute pyelonephritis; the strains of $P$. mirabilis and $S$. aureus used were laboratory strains (10). In some experiments, a strain of E. coli 055 was used, and this is noted in the text. In preparation for each experiment, a loopful of bacteria was transferred from a fresh agar slant culture to a $125 \mathrm{ml}$ Erlenmeyer flask containing $20 \mathrm{ml}$ of culture medium. The medium consisted of casamino acids, proteose peptone, and dextrose, prepared as previously described (11). The bacteria were grown overnight at $37^{\circ} \mathrm{C}$ in a shaker water bath and labeled with ${ }^{32} \mathrm{P}$ during growth (11). The labeled bacterial suspension was centrifuged, washed three times in phosphate buffer at $\mathrm{pH} 7.4$ to remove all unattached label, and resuspended in neutral phosphate buffer. This suspension was used as the bacterial inoculum.

Infection of animals. Female guinea pigs (275-300 g) were tied on their backs, and a No. 90 polyethylene catheter was inserted per urethra into the bladder. A No.
20 needle was fitted securely into the catheter and $1 \mathrm{ml}$ of the radioactive inoculum was injected into the bladder. The catheter, which remained in place for about $20 \mathrm{sec}$, was then removed. The animal was returned to its cage and allowed to void spontaneously.

A similar procedure was used for the infection of female rats (175-200 g, Charles River Laboratories, CD strain). The technique differed only in that a No. $261 \frac{1}{2}$ in. blunted needle was used instead of a catheter, the inoculum was only $0.1 \mathrm{ml}$, and ether anesthesia lasting about $1 \mathrm{~min}$ was utilized during catheterization.

Prcparation of tissue. The peritoneal cavity was entered under aseptic technique, the bladder was exposed, and the vesical neck clamped. The bladder was removed along with any residual urine within the lumen. With a No. 27 needle, the urine was aspirated, and a $1 \mathrm{ml}$ aliquot of sterile neutral phosphate buffer was injected into the bladder and removed by aspiration. This procedure was repeated three times with separate volumes of buffer. The total aspirate was combined with residual urine and labeled "washout." The clamp was then removed, and the bladder incised. With the mucosa exposed, the tissue was passed through three baths, each containing 2-ml of sterile phosphate buffer. The washed bladder was then homogenized in a ground glass homogenizer tube containing $2.5-\mathrm{ml}$ of trypticase soy broth until a homogeneous suspension was obtained. Pour plates were made in triplicate from serial dilutions of the bladder homogenates and the inoculum.

Radioactive counting. Samples of inoculum, the bladder homogenate, and washout fluid were prepared for radioactive counting. $1-\mathrm{ml}$ aliquots of the specimens were mixed with 4-ml of hyamine in disposable srrew cap vials and the mixture was digested at $60^{\circ} \mathrm{C}$ overnight. The next day, $5-\mathrm{ml}$ of $95 \%$ alcohol and $10-\mathrm{ml}$ of toluene scintillation solution ${ }^{1}$ were added to each vial to bring the total volume to $20-\mathrm{ml}$. All samples were counted for $10 \mathrm{~min}$ in a Packard-Tricarb model 3003 liquid scintillation counter. Correction for the quench effect of bladder mucosa was achieved in control vials containing $1 \mathrm{ml}$ of bladder homogenate, obtained from uninfected animals, and appropriate dilutions of the original inoculum.

Immunization of animals and determination of antilody titcrs. Guinea pigs received $0.1 \mathrm{ml}$ of a heat-killed $\left(56^{\circ} \mathrm{C}\right.$ for $30 \mathrm{~min}$ ) overnight culture of $P$. mirabilis or $S$. aurcus intraperitoneally at 3-day intervals for four doses and then $0.5 \mathrm{ml}$ of a live overnight culture of the same organism 3 days later. After $2 \mathrm{wk}$, the animals were exsanguinated by cardiac puncture. The blood was allowed to clot and the serum was separated and stored at $-20^{\circ} \mathrm{C}$. For determination of antibody titer, an $18 \mathrm{hr}$ broth culture of the test organism was centrifuged, resuspended in an equal volume of neutral phosphate buffer, and heated for $90 \mathrm{~min}$ at $60^{\circ} \mathrm{C}$. To serial twofold dilutions of serum was added an equal volume of bacterial suspension, diluted until it was barely turbid. This mix-

1 This solution contains $5 \mathrm{~g}$ of 2,5-diphenyloxazole (Packard) and $0.1 \mathrm{~g}$ of 1,4-bis-[2-(5-phenyloxazolyl)]benzene (Packard) dissolved in $1000 \mathrm{ml}$ of toluene. 
ture was incubated at $37^{\circ} \mathrm{C}$ for $1 \mathrm{hr}$, refrigerated for 18 $\mathrm{hr}$, and read macroscopically for agglutination the following morning. The reciprocal of the highest dilution showing bacterial agglutination was read as the titer for that serum.

Calculation of bacterial killing. The bactericidal activity of urinary bladder mucosa was determined by the method of Green and Goldstein (11). The radiotracer served as an inert marker to enumerate the total number of organisms in the original inoculum and the bladder. The bacterial killing in each bladder was calculated from the ratio $\left(R_{\mathbf{I}}\right)$ of viable bacterial count to radioactive count in the original inoculum (I), compared with the ratio $\left(R_{\mathbf{B}}\right)$ found in the homogenate of bladder (B) obtained from the infected animal. The ratio $\left(R_{\mathrm{B}}\right)$ divided by the ratio found in the inoculum $\left(R_{\mathrm{I}}\right)$ gives the per cent change in the proportion of viable bacteria attached to the bladder wall, during the elapsed time interval after infection. Thus :

(1) Per cent bacteria remaining viable on bladder wall

$$
\begin{aligned}
& \text { proportion of bacteria } \quad \frac{\text { bacterial count B }}{32 \mathrm{~PB}}
\end{aligned}
$$

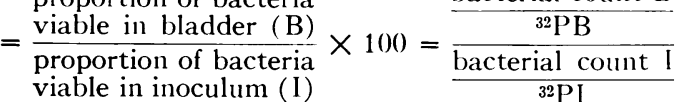

$$
\begin{aligned}
& \times 100=\frac{R_{\mathrm{B}}}{R_{\mathrm{I}}} \times 100 .
\end{aligned}
$$

It then follows that:

(2) Per cent bacteria killed on bladder wall $=100-$ per cent bacteria remaining viable on bladder wall

$$
=1-\frac{R_{\mathrm{B}}}{R_{\mathrm{I}}} \times 100 .
$$

Fig. 1 presents hypothetical applications of this technique. If, for example, the original inoculum of $1 \times 10^{\mathrm{s}}$ bacteria contained $1 \times 10^{6}$ radioactive counts (column 1 ), and after a certain time in the bladder, $1 \times 10^{6}$ radioactive counts, but only $1 \times 10^{7}$ bacteria were recovered, a 10 -fold loss of viability would have occurred with no voiding (column 2). On the other hand, after voiding it might be found that $1 \times 10^{5}$ bacteria with $1 \times 10^{3}$ radioactive counts remained, indicating a 1000 -fold loss of bacteria due to discharge of labeled bacteria, but no loss of viability (column 3 ). If the experiment showed $1 \times 10^{4}$ bacteria remaining with $1 \times 10^{3}$ radioactive counts, it would indicate a 1000 -fold loss of bacteria due to voiding

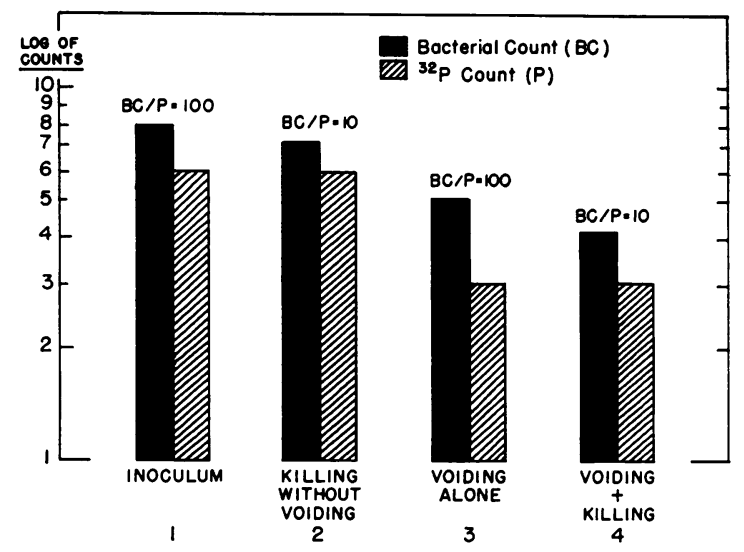

FIGURE 1 Schematic representation of method.

and an additional 10 -fold loss of viability within the bladder ( column 4 ).

\section{RESULTS}

Number of organisms removed by voiding. Animals infected with $1 \mathrm{ml}$ containing about $10^{9}$ bacteria voided within $10 \mathrm{~min}$ after challenge. The total number of bacteria remaining in the bladder after micturition was calculated from the radioactive counts present in the bladder homogenate and residual urine (Table I). The difference between this figure and the total radioactivity instilled into the bladder represents the radioactivity removed from the bladder by voiding. This assumes that all labeled bacteria either remain in the bladder or are voided in the urine. The assumption seems valid since samples of liver, spleen, kidneys, and serum showed either trace or no radioactivity $1 \mathrm{hr}$ after inoculation of organisms into the bladder. Table I shows data from groups of animals infected with $E$. coli or $S$. aureus and indicates the number of organisms removed by voiding. More than $99.9 \%$ of the

TABLE I

Effect of Voiding on Removal of Bacteria from the Bladder

\begin{tabular}{lcccccc}
\hline Organism & $\begin{array}{c}\text { Bacteria in- } \\
\text { jected into } \\
\text { bladder } \\
\times 10^{9}\end{array}$ & $\begin{array}{c}\text { Bacteria in } \\
\text { bladder } \\
\text { homogenate } \\
\times 10^{5}\end{array}$ & $\begin{array}{c}\text { Bacteria in } \\
\text { bladder } \\
\text { washout } \\
\times 10^{5}\end{array}$ & $\begin{array}{c}\text { Total bacteria } \\
\text { in bladder } \\
\text { after voiding } \\
\times 10^{5}\end{array}$ & $\begin{array}{c}\% \text { injected bac- } \\
\text { teria removed } \\
\text { by voiding }\end{array}$ \\
\hline $\begin{array}{l}\text { E. coli } \\
\text { S. } \text { aureus }\end{array}$ & 30 & $2.7 \pm 0.2^{*}$ & $2.0 \pm 0.7^{*}$ & $6.3 \pm 2.0^{*}$ & $8.3 \pm 2.1^{*}$ & $>99.9$ \\
P. mirabilis & 6 & $2.3 \pm 0.1$ & $0.9 \pm 0.3$ & $1.0 \pm 0.7$ & $1.9 \pm 0.8$ & $>99.9$ \\
\hline
\end{tabular}

* Mean \pm SE. 
TABLE II

Killing of E. coli by Guinea Pig Bladder in $1 \mathrm{hr}$

\begin{tabular}{|c|c|c|c|c|}
\hline \multirow[b]{2}{*}{ Sample } & \multirow[b]{2}{*}{ Bacterial count } & \multirow[b]{2}{*}{${ }^{32} \mathrm{P}$ count } & \multirow{2}{*}{ Ratio $\frac{\text { Bacterial count }}{{ }^{32} \mathrm{P} \text { count }}$} & \multirow{2}{*}{$\begin{array}{c}\% \text { bacteria } \\
\text { killed by } \\
\text { bladder wall* }\end{array}$} \\
\hline & & & & \\
\hline & No. bacteria/ml & counts/10 min per ml $\ddagger$ & & \\
\hline Inoculum & $2.5 \pm 0.1 \times 10^{9} \S$ & $6.0 \pm 0.2 \times 10^{8} \S$ & $4.1 \pm 0.1 \S$ & \\
\hline \multicolumn{5}{|c|}{ Homogenates of bladders } \\
\hline A & $1.1 \times 10^{3}$ & $6.1 \times 10^{3}$ & 0.18 & 95.6 \\
\hline B & $1.5 \times 10^{2}$ & $5.1 \times 10^{3}$ & 0.03 & 99.3 \\
\hline $\mathrm{C}$ & $7.8 \times 10^{2}$ & $1.1 \times 10^{4}$ & 0.07 & 99.3 \\
\hline $\mathrm{D}$ & $2.1 \times 10^{2}$ & $1.1 \times 10^{4}$ & 0.02 & 99.5 \\
\hline
\end{tabular}

* Calculated from formula (2) in Methods.

† Corrected for background.

$\S$ Mean \pm SE of determinations performed in triplicate.

total bacteria placed in the bladder were removed by voiding, and less than $0.1 \%$ remained in the bladder. This $0.1 \%$ residuum containing $10^{4}-10^{6}$ organisms was the subject of detailed investigation, since it represented that portion of the infective inoculum with which antibacterial mechanisms of the bladder had to contend.

Antibacterial activity of bladder. Table II shows the method of calculating bacterial killing in an experiment in which guinea pigs were inoculated with $E$. coli and killed $1 \mathrm{hr}$ later. Three aliquots of the inoculum were counted, and the ratio of viable bacteria to radioactive count was determined for each aliquot. The mean of the three aliquot ratios was calculated and served as the mean ratio for the inoculum. It is clear that the ratios obtained from each bladder homogenate are much lower than the mean values of the original inoculum, showing that there has been a marked loss of viability among those organisms attached to the bladder wall.

Fig. 2 shows the mean reduction in viability of those $E$. coli or $S$. aureus attached to the bladder wall at each time interval. E. coli were killed rapidly on the bladder wall; half of the organisms on the bladder wall $4 \mathrm{~min}$ after inoculation were no longer cultivable, and $85 \%$ were nonviable $30 \mathrm{~min}$ after infection. At $4 \mathrm{hr}$ after infection, the mean reduction in viability was $93 \%$, and at $6 \mathrm{hr}, 91 \%$. 1 animal of 12 showed bacterial multiplication on the bladder wall at $6 \mathrm{hr}$ after infection.

$S$. aureus, when introduced into guinea pig bladder, was not killed as rapidly as E. coli. At 1 $\mathrm{hr}$ after challenge, the mean reduction in viable organisms on the bladder wall was only $46 \%$, and there was greater variation in the rate of killing from animal to animal than was the case with $E$. coli. At $4 \mathrm{hr}$ after infection, there was a mean reduction of $67 \%$ in viability of those $S$. aureus remaining attached to the bladder wall. Of the 12 animals killed $6 \mathrm{hr}$ after infection with $S$. aureus, six showed multiplication of the organisms attached to the bladder wall, so that the mean percentage killed was reduced to only $22 \%$.

The ability of $S$. aureus and E. coli to multiply in the bladder urine differed markedly (Table III). $4 \mathrm{hr}$ after infection, multiplication of $E$. coli in the urine was significantly greater $(P<0.05)$ than the degree of multiplication seen for $S$. aureus. This is shown in Table III by the increase in ratio $\left(R_{\mathbf{U}}\right)$ of bacterial to radioactive counts in the urine compared with the ratio in the original inoc-

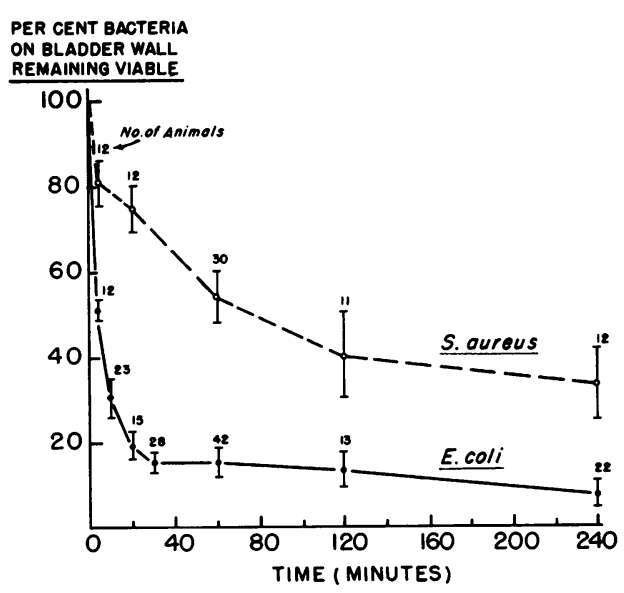

FIGURE 2 Bacterial killing by bladder wall. 
ulum $\left(R_{\mathrm{I}}\right)$. However, at the same time that $E$. coli were multiplying in the residual bladder urine, the bladder wall continued to exert a bactericidal effect on those organisms attached to its surface; the bladder homogenates at this time showed a 93\% reduction in viable organisms. In contrast, although $S$. aureus did not multiply vigorously in the urine, there was only moderate killing of this organism on the bladder wall $4 \mathrm{hr}$ after infection.

That the antibacterial activity of the bladder was not dependent on the species of animal used was shown in a series of experiments with rats. In addition to $E$. coli and $S$. aureus, a strain of $P$. mirabilis that readily causes pyelonephritis in rats was tested in both guinea pigs and rats to determine if it was handled comparably by the bladder. The ability of the bladder mucosa to inactivate different bacterial species is shown in Table IV for animals killed 60 min after infection. The bladders of guinea pigs and rats kill these strains of $E$. coli and $P$. mirabilis with equal facility, and both animal species exert a lesser bactericidal effect on S. aureus.

Methodologic controls. A series of experiments was carried out to exclude several potential sources of error in methods or interpretation of results.

(1) The method depends upon a firm binding of radiotracer and bacterium. Any significant separation would invalidate the meaning of the ratios of bacterial to radioactive counts. Firm binding of radioactive label and organism was demonstrated. Upon recentrifugation of the labeled bacterial inoculum, only $3-5 \%$ of the total radioactivity was found in the supernatant phase. $4 \mathrm{hr}$ later, $5-7 \%$ of radioactive counts was present in the supernatant phase. There is thus a slow loss of label from viable organisms which does not affect the interpretation of the results.

TABLE III

Viability of Bacteria on Bladder Wall and in Bladder Urine $4 \mathrm{hr}$ after Infection

\begin{tabular}{lcccc}
\hline Organism & $\begin{array}{c}\text { No. } \\
\text { animals }\end{array}$ & $R_{\mathrm{I}}$ & $R_{\mathrm{B}}$ & $R_{\mathrm{U}}$ \\
\hline E. coli & 6 & 10 & $0.7 \pm 0.3^{*}$ & $360 \pm 173^{*}$ \\
S. aureus & 8 & 10 & $3.3 \pm 1.0$ & $28 \pm 7$ \\
\hline
\end{tabular}

$R$, ratio bacterial to radioactive counts; I, inoculum; $\mathrm{B}$, bladder homogenate; $\mathrm{U}$, bladder urine.

* Mean \pm SE.
TABLE IV

Antibacterial Activity of the Bladder Wall

\begin{tabular}{llcc}
\hline Animal & Organism & $\begin{array}{c}\text { No. } \\
\text { animals } \\
\text { tested }\end{array}$ & $\begin{array}{c}\text { \% bacteria } \\
\text { killed in } \\
1 \mathrm{hr}\end{array}$ \\
\hline Guinea pig & E. coli & 42 & $85 \pm 3.8^{*}$ \\
& P. mirabilis & 15 & $91 \pm 3.4$ \\
& E. coli 055 & 8 & $92 \pm 4.5$ \\
& S. aureus & 30 & $46 \pm 6.4$ \\
Rat & E. coli & 10 & $88 \pm 3.6$ \\
& P. mirabilis & 11 & $89 \pm 4.2$ \\
& S. aureus & 8 & $58 \pm 8.2$ \\
\hline
\end{tabular}

* Mean \pm SE.

(2) Preferential attachment of killed bacteria or free tracer to the bladder wall might produce misleading results. To determine if nonviable organisms or free label had a greater affinity for the bladder wall than did labeled viable organisms, ${ }^{32} \mathrm{P}$-labeled viable $E$. coli, ${ }^{32} \mathrm{P}$-labeled heat-killed E. coli, and trypticase soy broth containing ${ }^{32} \mathrm{P}$ as $\mathrm{Na}_{2} \mathrm{HPO}_{4}$ but no bacteria, were injected into the bladders of three groups of guinea pigs (Table V). One-half of each group was killed within 4 min after inoculation, and the residual inoculum was removed by aspiration. The bladder was washed, homogenized, and assayed for residual radioactivity. The remaining guinea pigs were killed $1 \mathrm{hr}$ after voiding had occurred, and the bladder was handled identically. At $4 \mathrm{~min}$ after inoculation and again at $60 \mathrm{~min}$ after inoculation, there were no significant differences in the mean amounts of radioactivity attached to the bladder wall among the three groups of animals receiving viable bacteria, nonviable bacteria, or free label. $60 \mathrm{~min}$ after infection, the levels of radioactivity had fallen by 91,89 , and $88 \%$ in the animals receiving viable bacteria, nonviable bacteria, and free radiotracer, respectively. This clearly shows that there was no preferential attachment of nonviable organisms or free label to the bladder wall, nor was there increased excretion of either of these in the urine.

(3) The demonstration of an antibacterial activity of the bladder requires that the process of injecting the labeled inoculum or of homogenizing the bladder tissue does not alter the bacterial to radioactive ratio by exerting an antibacterial effect.

When the radioactive inoculum was aspirated 
TABLE V

Uptake of Radioactivity by Bladder Wall

\begin{tabular}{|c|c|c|c|c|}
\hline Material injected into bladder & $\begin{array}{l}\text { Time after } \\
\text { injection } \\
\text { into bladder }\end{array}$ & $\begin{array}{c}\text { No. } \\
\text { animals }\end{array}$ & $\begin{array}{l}\text { Radioactive } \\
\text { count injected* }\end{array}$ & $\begin{array}{l}\text { Radioactive count } \\
\text { present on } \\
\text { bladder wall } \ddagger\end{array}$ \\
\hline & $\min$ & & & \\
\hline Viable, labeled $E$. coli & 4 & 6 & $1.0 \times 10^{8}$ & $6.0 \pm 4.7 \times 10^{5}$ \\
\hline Heat-killed, labeled $E$. coli & 4 & 6 & $1.0 \times 10^{8}$ & $3.0 \pm 2.4 \times 10^{5}$ \\
\hline${ }^{32} \mathrm{P}$ in sterile broth & 4 & 6 & $1.0 \times 10^{8}$ & $2.5 \pm 1.2 \times 10^{5}$ \\
\hline Viable, labeled $E$. coli & 60 & 6 & $1.0 \times 10^{8}$ & $5.3 \pm 2.2 \times 10^{4}$ \\
\hline Heat-killed, labeled E. coli & 60 & 6 & $1.0 \times 10^{8}$ & $3.2 \pm 2.2 \times 10^{4}$ \\
\hline${ }^{32} \mathrm{P}$ in sterile broth & 60 & 6 & $1.0 \times 10^{8}$ & $3.1 \pm 2.5 \times 10^{4}$ \\
\hline
\end{tabular}

* Mean No. counts/10 min per ml.

$\ddagger$ Mean No. counts in bladder homogenates $/ 10 \mathrm{~min}$ per $\mathrm{ml} \pm \mathrm{SE}$.

from the bladder immediately after injection through the catheter, no change was noted in the ratio of bacterial to radioactive counts from that of the original inoculum. The neutral phosphate buffer used to wash the bladders exhibited no antibacterial activity. The final wash of the bladder, before homogenization, contained less than $0.01 \%$ of the total radioactivity present in the homogenate. This finding suggested that there was a firm attachment of residual bacteria to the bladder wall and that this attachment was not disturbed by the process of washing.

To exclude the possible artifact of bacterial killing or clumping due to the process of homogenization, these experiments were performed. The same inoculum of ${ }^{32} \mathrm{P}$-labeled $E$. coli as was injected into the living animal (about $10^{9}$ bacteria) was placed in an homogenizer containing $2.5 \mathrm{ml}$ of trypticase soy broth and an uninfected guinea pig bladder. Comparable studies were also done using an inoculum of about $10^{5} \mathrm{E}$. coli. The mixture was ground together for the same duration of time as in experiments with bladders from infected animals, until a homogeneous suspension was obtained. The results of eight such experiments are shown in Table VI. No significant change in bacterial to radioactive ratio was noted in homogenates when compared with the original inoculum.

Homogenates of bladders from uninfected guinea pigs or rats were made in $1 \mathrm{ml}$ of trypticase soy broth and incubated with $10^{3} \mathrm{E}$. coli. There was no antibacterial activity. Fig. 3 shows that the growth curve of these organisms in bladder homogenates over a $4 \mathrm{hr}$ period closely paralleled that in trypticase soy broth alone.

These experiments demonstrate that neither the

TABLE VI

Effect of Homogenization on Bacterial-Radioactive Ratio

\begin{tabular}{|c|c|c|c|c|c|}
\hline \multicolumn{3}{|c|}{ Inoculum } & \multicolumn{3}{|c|}{ Homogenate } \\
\hline \multirow[b]{2}{*}{ Bacterial count } & \multirow[b]{2}{*}{${ }^{32} \mathrm{P}$ count } & \multirow{2}{*}{ Ratio $\frac{\text { Bacterial count }}{{ }^{22} \mathrm{P} \text { count }}$} & \multirow[b]{2}{*}{ Bacterial count } & \multirow[b]{2}{*}{${ }^{32} \mathrm{P}$ count } & Bacterial count \\
\hline & & & & & ${ }^{82} \mathrm{P}$ count \\
\hline No. bacteria $/ \mathrm{ml}$ & counts/10 min per ml & & No. bacteria $/ m l$ & counts/10 min per ml & \\
\hline $1.1 \times 10^{9}$ & $4.7 \times 10^{7}$ & 23.4 & $1.4 \times 10^{8}$ & $6.0 \times 10^{6}$ & 23.3 \\
\hline $1.1 \times 10^{9}$ & $4.7 \times 10^{7}$ & 23.4 & $1.9 \times 10^{8}$ & $8.1 \times 10^{6}$ & 23.5 \\
\hline $1.6 \times 10^{9}$ & $7.4 \times 10^{7}$ & 21.6 & $1.9 \times 10^{8}$ & $8.8 \times 10^{6}$ & 21.6 \\
\hline $1.6 \times 10^{9}$ & $7.4 \times 10^{7}$ & 21.6 & $1.8 \times 10^{8}$ & $8.2 \times 10^{6}$ & 22.0 \\
\hline $1.4 \times 10^{5}$ & $6.0 \times 10^{3}$ & 23.3 & $2.6 \times 10^{4}$ & $1.1 \times 10^{3}$ & 23.6 \\
\hline $1.4 \times 10^{5}$ & $6.0 \times 10^{3}$ & 23.3 & $1.9 \times 10^{4}$ & $8.1 \times 10^{2}$ & 23.5 \\
\hline $1.8 \times 10^{5}$ & $7.2 \times 10^{3}$ & 25.0 & $2.2 \times 10^{4}$ & $8.8 \times 10^{2}$ & 25.0 \\
\hline $1.8 \times 10^{5}$ & $7.2 \times 10^{3}$ & 25.0 & $2.1 \times 10^{4}$ & $8.3 \times 10^{2}$ & 25.3 \\
\hline
\end{tabular}




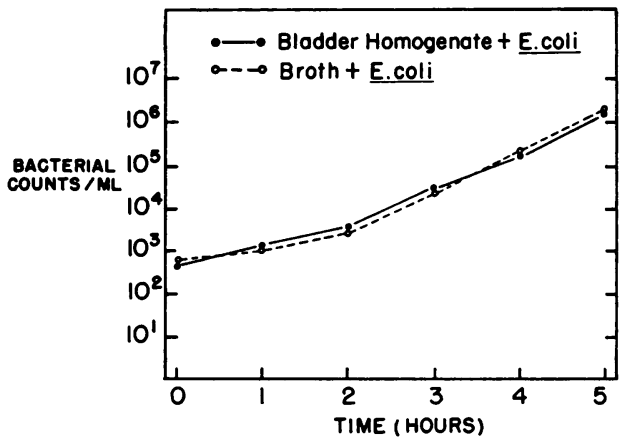

Figure 3 Growth of $E$. coli in nutrient broth and in homogenates of bladder.

process of injection of bacteria into the bladder nor the homogenization of the bladder alters the bacterial to radioactive ratio. No antibacterial activity of bladder homogenates could be demonstrated.

Antibacterial activity of guinea pig urine. Guinea pig urine might have antibacterial properties that would explain the loss of viability of organisms introduced into the bladder. To exclude such a mechanism, urine was obtained by catheterization from 19 uninfected guinea pigs. To $1 \mathrm{ml}$ of urine was added $1 \mathrm{ml}$ of bacterial suspension containing approximately $10^{3} \mathrm{E}$. coli. The mixture was incubated at $37^{\circ} \mathrm{C}$ for $24 \mathrm{hr}$. Only one urine sample showed any bactericidal activity at 1 and $24 \mathrm{hr}$. The other 18 supported bacterial multiplication with final concentrations at $24 \mathrm{hr}$ ranging from $2 \times 10^{8}$ to $4 \times 10^{8}$ organisms $/ \mathrm{ml}$. Trypticase soy broth incubated $24 \mathrm{hr}$ with $E$. coli invariably yielded final concentrations of $1-3 \times 10^{9}$ bacteria/ml.

Studies with excised bladders. Experiments were carried out with excised bladders in an attempt to learn if the bactericidal properties of the bladder demonstrated in intact animals could be reproduced in vitro. Guinea pigs were killed by intraperitoneal administration of pentobarbital. The bladders were clamped, removed aseptically, and held in a moistened Petri dish. Radioactive inoculum was injected into the bladder lumen through a No. 27 needle. After an appropriate interval, the inoculum was removed by aspiration, and the bladder was washed, homogenized and examined as previously described. When labeled inocula of $E$. coli were removed $1 \mathrm{~min}$ after injection into the excised bladder, there was a mean reduction of $55 \%$ in viable organisms remaining attached to the bladder wall (Table VII). This was comparable with the results obtained when the bladder was left in situ and the inoculum was removed within $3 \mathrm{~min}$ after infection. However, if the inoculum was removed from the excised bladder $1 \mathrm{~min}$ after injection, and the bladder held at room temperature or $37^{\circ} \mathrm{C}$ for $1 \mathrm{hr}$ before homogenizing, the mean reduction in viability of these organisms attached to the wall remained at $55 \%$. The excised bladder did not exhibit the progressive killing of attached bacteria that was seen in the intact animal (Table VII).

The mean reduction in viability of $55 \% 1 \mathrm{hr}$ after challenge was unchanged even when the bladder was held at 4 or $37^{\circ}$ for $2 \mathrm{hr}$ before challenge, or when the actual inoculation of the bladder was carried out at $4^{\circ} \mathrm{C}$ (Table VIII). Placing killed $E$. coli into the bladder for $1 \mathrm{hr}$ before to challenge with the same strain of live E. coli did not alter the rate of killing of these viable bacteria attached to the bladder wall. Vigorous washing of the bladder wall with sterile phosphate buffer before inoculation of bacteria had no effect on bacterial killing (Table VIII).

Effect of immunization. Guinea pigs were im-

TABLE VII

Bacterial Killing in Intact and Excised Bladders

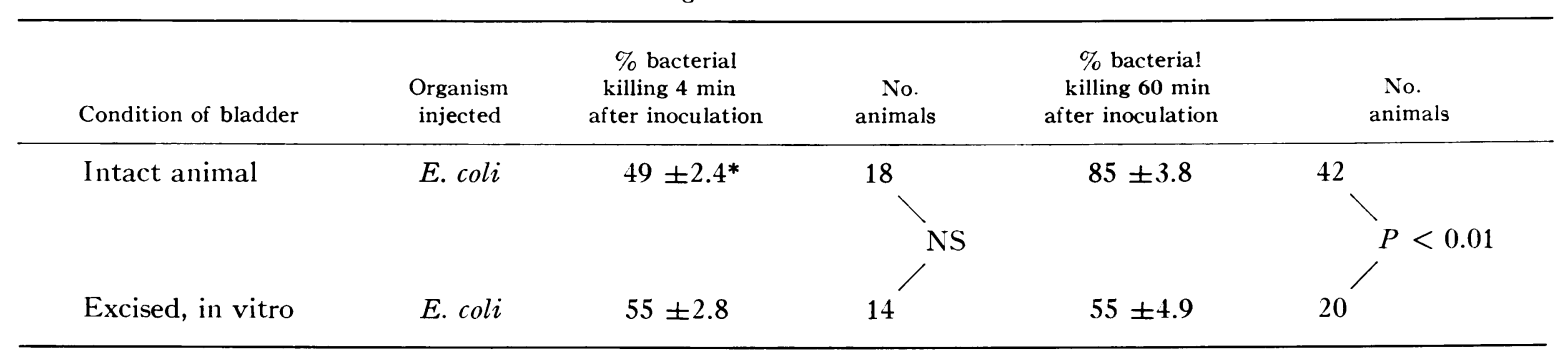

\footnotetext{
$*$ Mean \pm SE.
} 
munized with $P$. mirabilis or $S$. aureus to learn if production of antibody played any role in the antibacterial activity of the bladder. $P$. mirabilis was used, since this laboratory strain has been shown to be an effective immunizing agent (10). $S$. aureus was employed since it would not be expected to be affected directly by antibody. Sera from guinea pigs immunized with $P$. mirabilis gave antibody titers of 160 or greater, whereas control nonimmunized animals had no detectable antibody at 1:2 dilutions of serum. At $20 \mathrm{~min}$ after infection, immunized and nonimmunized guinea pigs were killed and their bladders examined. The nonimmunized guinea pigs showed a mean bacterial killing of $69 \%$ and the immunized $76 \%$, a difference that is not statistically significant (Table IX).

Comparable experiments were performed with $S$. aureus as the immunizing agent. No increase in killing of this organism by the bladder was seen in immunized guinea pigs as opposed to controls (Table IX).

Clumping of bacteria. Were bacteria to clump together on the bladder wall, they would grow as a single colony when pour plates were made from bladder homogenates. The falsely lowered total bacterial count produced in this way could account for a reduction in the bacterial to radioactive ratio, and suggest a killing action. To examine

TABLE VIII

Effect of Various Conditions on Bacterial Killing by Excised Bladder

\begin{tabular}{lcc}
\hline \multicolumn{1}{c}{ Condition of bladder } & $\begin{array}{c}\text { No. } \\
\text { animals }\end{array}$ & $\begin{array}{c}\% \text { bacterial killing } \\
\text { in excised bladder } \\
\mathbf{~ h r} \text { after infection }\end{array}$ \\
\hline $\begin{array}{l}\text { Infected immediately after } \\
\text { excision }\end{array}$ & 12 & $55 \pm 2.8^{*}$ \\
$\begin{array}{l}\text { Held at room temperature } \\
\text { for } 1 \text { hr before infection }\end{array}$ & 9 & $52 \pm 3.1$ \\
$\begin{array}{l}\text { Held at } 4^{\circ} \mathrm{C} \text { for } 2 \text { hr before } \\
\text { infection }\end{array}$ & 10 & $54 \pm 2.9$ \\
$\begin{array}{l}\text { Held at } 37^{\circ} \mathrm{C} \text { for } 2 \text { hr before } \\
\text { infection }\end{array}$ & 10 & $51 \pm 3.0$ \\
$\begin{array}{l}\text { Washed with phosphate } \\
\text { buffer } 2 \text { hr before in- } \\
\text { fection }\end{array}$ & 10 & $52 \pm 3.2$ \\
$\begin{array}{l}\text { Killed } E \text {. coli } \text { placed in } \\
\text { bladder for } 1 \text { hr before } \\
\text { infection with viable } \\
\text { E. coli }\end{array}$ & 11 & $52 \pm 2.8$ \\
\hline
\end{tabular}

$*$ Mean \pm SE.
TABLE IX

Effect of Immunization on Bacterial Killing by Bladder Wall

\begin{tabular}{llcll}
\hline Organism & $\begin{array}{c}\text { Immune state } \\
\text { of animal }\end{array}$ & $\begin{array}{c}\text { No. } \\
\text { animals }\end{array}$ & $\begin{array}{c}\text { \% killing of bacteria } \\
\text { attached to bladder } \\
\text { wall }\end{array}$ \\
\hline P. mirabilis & Control & 11 & $69 \pm 4.0^{*}$ & $P>0.1$ \\
& Immunized & 8 & $76 \pm 3.6$ & $P$ \\
S. aureus & Control & 30 & $46 \pm 6.4$ & $P>0.1$ \\
& Immunized & 19 & $35 \pm 7.4$ & $P$
\end{tabular}

* Mean \pm SE.

this possibility, bladders from guinea pigs infected with $E$. coli $055^{2}$ were removed $1 \mathrm{hr}$ after infection. Impression smears of the exposed mucosa were stained with specific immunofluorescent antibody. If clumping were responsible for the reduction in colony-forming units, $99 \%$ reduction would mean that bacteria were clumping in groups of approximately 100 . Instead, although few organisms were seen on the slides, the bacteria were observed singly or occasionally in pairs. At no time when significant killing of organisms had occurred were large clumps of bacteria seen. No bacterial clumps were seen in frozen tissue sections stained with Giemsa stain, but single and paired organisms were seen in the lumen (Fig. 4).

Cell counts and sections of the bladder. Bladders were removed from control animals, from animals catheterized and challenged with E. coli, and from animals catheterized and given sterile phosphate buffer into the bladder. Cell counts performed on the "washouts" obtained $1 \mathrm{hr}$ after infection revealed red blood cells and epithelial cells. Only a rare lymphocyte and no polymorphonuclear leukocytes were seen. Fixed tissue sections of unwashed bladder from comparably challenged animals sacrificed $1 \mathrm{hr}$ after infection showed no inflammatory response and only a rare polymorphonuclear leukocyte in the bladder lumen.

Effect of varying inoculum size. It was observed in early experiments that those bladders with high radioactive counts often exhibited lower rates of bacterial killing than did bladders with fewer retained radioactive counts. To determine if the number of bacteria attached to the bladder

2 This organism was selected because it had been shown to be killed by the bladder (Table IV) and because. commercially prepared specific fluorescent antiserum was available. 


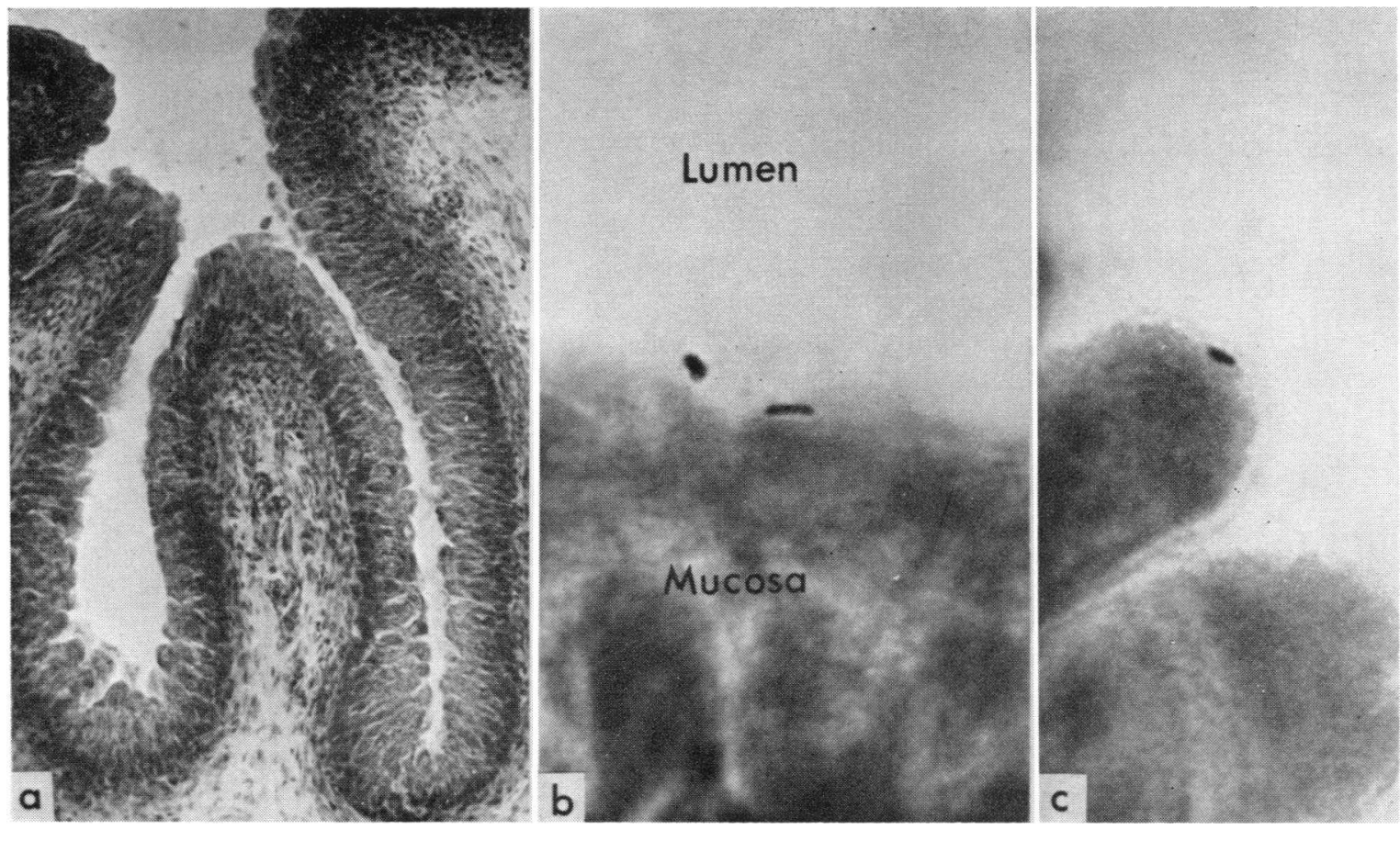

FIGURE 4 (a) Histological frozen section from mucosa of guinea pig bladder $1 \mathrm{hr}$ after inoculation with $1 \times 10^{\circ}$ E. coli. Note that the mucous membrane is intact and that there is no evidence of acute inflammation in this section. Stained with Giemsa stain. $\times 130$. $(b)$ and $(c)$ Higher magnification of two areas from the same section as $(a)$ to show single $(c)$ and probably paired $(b)$ organisms adherent to the bladder mucosa. $\times 1180$.

wall affected the rate of bacterial killing, guinea pigs were given into the bladder undiluted, $1: 10$, and $1: 100$ dilutions of a radiotracer-labeled bacterial inoculum and were sacrificed immediately. The mean reduction in viability of those bacteria attached to the bladder wall 4 min after inoculation was determined for eight animals with greater than $10^{4}$ radioactive counts, and for 10 with less than $10^{4}$ radioactive counts. The mean killing was $52 \%$ \pm 3.2 for the group with a greater residual activity and $69 \% \pm 3.7$ for those animals with fewer organisms attached to the wall, a difference that is statistically significant $(P<0.01)$.

\section{DISCUSSION}

These experiments have demonstrated the following: (1) More than $99.9 \%$ of bacteria injected into the bladder are removed by voiding, and less than $0.1 \%\left(10^{4}-10^{6}\right.$ organisms $)$ remain in the residual urine or attached to the bladder wall. These remaining bacteria provide a sufficient inoculum to perpetuate infection within the bladder if their growth is uninhibited. (2) Guinea pig and rat bladders exhibit rapid killing of $E$. coli and
P. mirabilis that become attached to the mucosa. In contrast, $S$. aureus is not killed as rapidly or as efficiently by the bladder. (3) Multiplication of $E$. coli within the residual bladder urine occurs at a time when the bladder mucosa is still exerting an antibacterial effect on organisms attached to its surface. (4) Theoretical objections to the experimental method have been studied and excluded. (5) The excised bladder exerts an initial rapid antibacterial effect, but it does not exhibit the progressive killing over time seen in the intact animal. (6) No evidence of bacterial clumping or of phagocytosis is seen.

It is clear that the bladder possesses intrinsic antibacterial activity. Because the experimental method allowed voiding to occur naturally, the simultaneous study of both bladder antibacterial activity and mechanical clearance of bacteria was possible under physiologic conditions. The reliability of the radiotracer method depends upon firm binding of the radioactive label to the live bacteria. The stability of the label used in the experiments, and the viability of these organisms over the course of experiments has been demonstrated 
previously for $P$. mirabilis (10) and in the present studies for E. coli.

Vivaldi et al. (6), using an exteriorized rabbit bladder to which $E$. coli was applied in minute volumes, showed significant reductions in viability of the microorganisms $1 \mathrm{hr}$ after application to the mucosa. They further showed, using radiolabeled bacteria, that the label persisted in the bladder wall when viability had decreased, a finding that suggests rapid and efficient killing of bacteria by the bladder mucosa.

Cobbs and Kaye (7), using rats with bilaterally ligated ureters, showed striking antibacterial activity of the rat bladder against two strains of $E$. coli and lesser activity against a third strain of E. coli and against P. mirabilis. Antibacterial activity was totally abolished if the bladder outflow tract was obstructed.

In contrast, Mulholland et al. (9) were unable to demonstrate any inhibition of bacterial growth in rabbits in which only ureters were ligated and $E$. coli instilled into the bladder in minute volume. This negative finding resulted despite the fact that 8 of 20 normally voiding rabbits sterilized their urine within $72 \mathrm{hr}$ after introduction of one million E. coli.

The reasons for the discrepancies in results among various investigators are not entirely clear. It is possible that the rabbit bladder possesses no antibacterial activity or that the bacterial strains used were resistant to the antibacterial properties of the bladder. Each of the experimental models was artificial to some extent, in that each involved surgical manipulation and prevention of voiding in order to study the action of the bladder wall. The system reported herein avoided these difficulties, since a catheter was inserted only briefly and the unanesthetized animals were allowed to void freely. Further, unless the bladder wall is thoroughly washed before homogenization, it may remain contaminated with residual urine. Urine has been shown in our system to support bacterial multiplication at a time when the bladder mucosa is still exerting a bactericidal effect. Therefore, reports that examine only the total bacterial count in the bladder at $4-6 \mathrm{hr}$ after infection may, if multiplication has occurred in the residual urine, totally overlook any antibacterial activity of the badder wall itself.

The mechanisms of the antibacterial activity of the bladder are as yet unclear. Clumping of bacteria, such that many organisms form a unit that will grow as a single colony on agar, has been suggested as a means of accounting for the reduction in viability seen in experimental models. However, histologic sections and impression smears failed to demonstrate clumping in experiments in which clumps as large as 100 bacteria would have to be invoked to explain the reduction in viable numbers of organisms.

A possible mechanism for reduction in viable numbers of bacteria in the bladder could be phagocytosis and killing of organisms by leukocytes, or by bladder mucosa. Cobbs and Kaye (7) demonstrated an inflammatory response that occurred in the bladder after bacteria were introduced. These investigators demonstrated histologic evidence of inflammation $2 \mathrm{hr}$ after introduction of bacteria into rat bladder and an increase in polymorphonuclear leukocytes in the bladder "washout" $4 \mathrm{hr}$ after infection. In the present study, reduction in viability occurred within a few minutes and no evidence of an inflammatory reaction was seen even $1 \mathrm{hr}$ after infection, when only a rare leukocyte could be recovered by washing the bladder wall. Thus, at a time when $85-90 \%$ reduction in viability of the bacteria attached to the bladder wall had occurred, no evidence of inflammation or of polymorphonuclear leukocyte mobilization was seen. It seems likely that phagocytosis and killing of bacteria do occurs in the bladder over a period of time, but it is difficult to invoke this to explain the extremely rapid reduction in viability seen in the 1 st hr after infection. O. Kunii and E. $H$. Kass (unpublished data) were unable to show any evidence that bladder mucosal cells could phagocytize bacteria.

The rapid reduction in viable bacteria demonstrated in our model makes antibody a possible mechanism for the antibacterial activity of the bladder. Against this is the evidence that active immunization of guinea pigs with $P$. mirabilis, which produced significant titers of antibody in the serum, did not enhance the degree of killing of $P$. mirabilis by the bladder. Further, prior instillation of killed $E$. coli into the excised guinea pig bladder and subsequent challenge with the same strain of viable $E$. coli did not alter the reduction in viability of bacteria produced by the bladder. S. aureus is an organism against which 
antibody should not be effective, yet a certain degree of killing of the bacteria occurred on the bladder wall, a finding that suggests again that antibody is not of great significance in this phenomenon. These data indicate that antibody does not play a major role in the antibacterial activity of the bladder.

An alternative possibility might be the presence of organic acids or other substances that might create an environment at the bladder mucosal surface unfavorable to bacterial growth (12). The antibacterial action of organic acids is related to the number of undissociated acid molecules present. If a critical $\mathrm{pH}$ were to be achieved at the interface of bladder mucosa and urine, organic acids (present as end products of cellular metabolism) could exert an antibacterial effect. At present no direct evidence exists to support or refute such a hypothesis.

Although the mechanism for the antibacterial activity of the bladder remains unclear, it can be suggested that a substance (as yet unidentified) exists in the bladder wall which is used and replenished as the intact bladder exerts its antibacterial activity. The following evidence can be cited as support.

When $E$. coli is placed into the bladder of the intact animal, viability of the bacteria attached to the bladder wall begins to be lost promplty and continues to decrease with time. In contrast, in the excised bladder an immediate reduction in viability ocurs (as in the intact animal), but no further bacterial killing occurs with time. Thus, in the intact bladder the mechanism for bacterial killing is not exhausted, whereas in the excised bladder, after an initial effect, there is a lack of further antibacterial activity.

Secondly, it has been shown that decreasing the size of the inoculum applied to the bladder wall significantly increases the per cent of organisms killed by the wall. This "inoculum effect" again suggests a substance that has a finite capacity to handle a certain number of organisms and whose antibacterial activity may be overcome by increasing the numbers of organisms with which it must contend.

The significance of the antibacterial activity of the bladder in handling an infecting inoculum is still unclear. It is reasonable to think that the anti- bacterial activity of the bladder acts to inhibit multiplication of organisms between voidings, and by so doing hastens the clearance of bacteria from the bladder. However, in this experimental system $S$. aureus, which is not a usual urinary tract pathogen in rats (when inoculated into the bladder), was poorly killed by the bladder mucosa, whereas $P$. mirabilis, a known urinary pathogen in rats, was killed rapidly by the bladder mucosa. It is difficult presently to reconcile these experimental results with the theoretical possibility that the susceptibility of some individuals to urinary tract infection may be due to relatively decreased antibacterial activity of the bladder. Despite these difficulties, it is clear that the bladder possesses intrinsic antibacterial activity. The role and significance of this mechanism in the pathogenesis of urinary tract infections clearly warrants further investigation.

\section{ACKNOWLEDGMENTS}

We are grateful to Miss Anne Gillespie and Miss Rose Mary Bacina for excellent technical assistance. We thank Dr. Ramzi Cotran for his assistance with the histologic material and for his encouragement and advice. We are indebted to Dr. Paul Levy for statistical advice given during this study.

This work was supported by grants T1-AI-00068 and AI-06577 from the National Institute of Allergy and Infectious Diseases, and grant 176B from the New York Tuberculosis and Health Association, Inc.

\section{REFERENCES}

1. Vivaldi, E., R. Cotran, D. P. Zangwill, and E. H. Kass. 1959. Ascending infection as a mechanism in the pathogenesis of experimental non-obstructive pyelonephritis. Proc. Soc. Exptl. Biol. Med. 102: 242.

2. Cotran, R. S., E. Vivaldi, D. P. Zangwill, and E. H. Kass. 1963. Retrograde Proteus pyelonephritis in rats. Am. J. Pathol. 43: 1.

3. Cox, C., and F. Hinman. 1961. Experiments with induced bacteriuria, vesical emptying and bacterial growth on the mechanism of bladder defense to infection. J. Urol. 86: 739.

4. Cotran, R. S., L. D. Thrupp, S. N. Hajj, D. P. Zangwill, E. Vivaldi, and E. H. Kass. 1963. Retrograde $E$. coli pyelonephritis in the rat: a bacteriologic, pathologic and fluorescent antibody study. $J$. Lab. Clin. Med. 61 : 987.

5. Cox, C., and F. Hinman. 1965. Factors in resistance to infection in the bladder. I. The eradication of bacteria by vesical emptying and intrinsic defense mechanisms. In Progress in Pyelonephritis. E. H. Kass, editor. F. A. Davis Company, Philadelphia. 563. 
6. Vivaldi, E., J. Muñoz, R. S. Cotran, and E. H. Kass. 1965. Factors affecting the clearance of bacteria within the urinary tract. In Progress in Pyelonephritis. E. H. Kass, editor. F. A. Davis Company, Philadelphia. 531.

7. Cobbs, C., and D. Kaye. 1967. Antibacterial mechanisms in the urinary bladder. Yale J. Biol. Med. 40: 93.

8. Paquin, A., J. Perez, C. Kunin, and E. Foster. 1965. Does the bladder possess an intrinsic antibacterial defense mechanism? J. Clin. Invest. 44: 1084.
9. Mulholland, G., E. Foster, J. Gillenwater, and A. Paquin. 1966. Effect of vesical mucosa on bacterial growth. Clin. Res. 14: 341 .

10. Green, G. M., and E. H. Kass. 1964. The role of the alveolar macrophage in the clearance of bacteria from the lung. J. Exptl. Med. 119: 167.

11. Green, G. M., and E. Goldstein. 1966. A method for quantitating intrapulmonary bacterial inactivation in individual animals. J. Lab. Clin. Med. 68: 669.

12. Kass, E. H. 1960. Bacteriuria and the pathogenesis of pyelonephritis. Lab. Invest. 9: 110. 